\title{
LONG-CHAIN ALIPHATIC WAX ESTERS ISOLATED FROM THE SPONGE Chalinula saudensis (DEMOSPONGIA) ALONG THE JEDDAH COAST OF THE RED SEA
}

\author{
Abdulmohsin Al-Sofyani ${ }^{1 *}$, Radwan K. Al-Farawati ${ }^{2}$, Amr A. ElMaradny $^{2}$ and Gul R. Niaz \\ ${ }^{1}$ Department of Marine Biology, Faculty of Marine Science \\ (King Abdulaziz University, P.O.Box. 80207, Jeddah-21589, Saudi Arabia) \\ ${ }^{2}$ Department of Marine Chemistry, Faculty of Marine Science, \\ (King Abdulaziz University, P.O.Box. 80207, Jeddah-21589, Saudi Arabia) \\ *Corresponding author: rfarawati@kau.edu.sa
}

\begin{abstract}
A B S TR A C T
The sponge Chalinula saudensis, which occurs along the Jeddah coast, has only recently been isolated and identified. In this study, the total crude organic matter of the sponge was extracted by solvents. The total crude extract was further separated by partitioning it with hexane and water, then with water and chloroform, and finally with water and t-butanol. The chloroform layer was subjected to separation by preparative layer chromatography on silica. One fraction contained four long-chain fatty acid esters, $\mathrm{C}_{28} \mathrm{H}_{56} \mathrm{O}_{2}, \mathrm{C}_{30} \mathrm{H}_{60} \mathrm{O}_{2}, \mathrm{C}_{32} \mathrm{H}_{62} \mathrm{O}_{2}$ and $\mathrm{C}_{36} \mathrm{H}_{70} \mathrm{O}_{2}$. The second ester, $\mathrm{C}_{30} \mathrm{H}_{60} \mathrm{O}_{2}$, has been identified in the fire corals Millepora dichotoma and Millepora platyphylla. The others have not previously been reported from marine organisms; however similar long-chain esters with different long aliphatic chains and with different molecular weights have been identified from other marine organisms. These compounds are normally waxy and their presence in Chalinula saudensis plays a vital role in the biosynthetic pathways. They also act as insulators against seasonal variations.
\end{abstract}

\section{RESUMO}

A esponja Chalinula saudensis ocorre ao longo da costa de Jeddah, Arabia Saudita, mas apenas recentemente foi isolada e identificada. No presente estudo a matéria orgânica total da esponja foi extraída por solventes e o extrato foi separado por partição sucessiva através do emprego de hexano e água, clorofórmio e água e finalmente t-butanol e água. A camada contendo clorofórmio foi então separada por cromatografia em sílica. Os resultados mostraram a presença de ésteres de quatro ácidos graxos de cadeira longa $\left(\mathrm{C}_{28} \mathrm{H}_{56} \mathrm{O}_{2}, \mathrm{C}_{30} \mathrm{H}_{60} \mathrm{O}_{2}, \mathrm{C}_{32} \mathrm{H}_{62} \mathrm{O}_{2}\right.$ e $\left.\mathrm{C}_{36} \mathrm{H}_{70} \mathrm{O}_{2}\right)$, sendo que o segundo deles foi também identificado nos corais Millepora dichotoma e Millepora platyphylla. Não se tem evidência da presença dos demais compostos em outros organismos marinhos, embora haja relatos para ésteres semelhantes de cadeia longa, mas contendo diferentes cadeias alifáticas e diferentes pesos moleculares. Os compostos isolados em C. saudensis são geralmente ceras e sua presença na esponja tem importância não só nas rotas de biosíntese, mas servem como isolantes nas variações sazonais adversas.

Descriptors: Chalinula saudensis, Fatty acid esters, Jeddah coast.

Descritores: Chalinula saudensis, Ácidos graxos, Costa de Jeddah.

\section{INTRODUCTION}

Chalinula saudensis is a rare sponge. It was identified for the first time in the Red Sea along the Jeddah coast. The taxonomic identification was undertaken jointly by French and Saudi scientists (VACELET et al., 2001). It belongs to the class Demospongia, order Haploscelroida, and family Chalinidae. This is a rare sponge in the sense that it has been found in very small quantities and has its full blooming season during the months of November-
December. Because it is a new species, very little work has been done on it. We sought, therefore, to identify some of its chemical constituents. This marine organism is contained within with a thick, round, irregular crust. It is attached to the substratum by a short thick peduncle with oscules located on its upper surface. The colony is $30 \mathrm{~cm}$ in maximum extension and is found at a depth of $20-30 \mathrm{~m}$, close to the black coral (Antipathes $s p$ ). It is vivid blue in life and has a soft resilient body (Fig. 5). 


\section{Material ANd Methods}

The sponge Chalinula saudensis was brought from near the mouth Obhur Creek on the Jeddah coast. It was removed by hand from a hard substrate, of a mainly black dead coral skeleton, by the diver (Al-SOFYANI). There were variations in the temperature, $\mathrm{pH}$ and salinity of the sea water in the various seasons. During the summer the temperature of the water column was $27.0^{\circ} \mathrm{C}$, $\mathrm{pH}$ was 8.27 and the salinity was $39.83 \%$, whereas in winter the temperature of the water column was $25.5^{\circ} \mathrm{C}, \mathrm{pH}$ was 8.02 and the salinity was $39.48 \%$. The specimen was taken to the laboratory immediately and washed with sea water; it was then dried and subjected to solvent extraction (methanol: chloroform: water, 2:4:1, v/v). It was stirred at room temperature for 24 hours and then filtered. The residue was subjected to a second solvent extraction and the two extracts were combined and evaporated to dryness under vacuum. It was observed that $71 \mathrm{gm}$ of the wet organism yielded $253 \mathrm{mg}$ of crude extract. The crude extract was partitioned with hexane: water $(1: 1, \mathrm{v} / \mathrm{v})$, shaken vigorously and then separated. The water layer was again taken up in an equal volume of chloroform and the water layer was separated. This water layer was finally partitioned with t-butanol and the two layers were separated. The chloroform layer was treated with anhydrous sodium sulfate to remove traces of moisture. It was then evaporated to dryness under vacuum. The gummy material was dissolved in a little chloroform and applied to a silica preparative-layer chromatography plate (1 mm thickness). It was developed in a solvent system (methanol:chloroform, 5:95 ; v/v). Spots with an $R_{f}$ value of 0.6 were eluted from the plate, dissolved in chloroform, filtered, and evaporated. It was further purified in a small column containing neutral alumina (grade III, 6" $\times 0.5 "$ ) and finally evaporated. Attempts made to crystallize it were unsuccessful.

Samples were analyzed by GC-MS, on a Shimadzu QP-2010. The instrument was programmed as follows: injector temperature was $250^{\circ} \mathrm{C}$, the injection mode was split, and the initial column temperature was $50^{\circ} \mathrm{C}$ (held for one min); it was increased at a rate of $10^{\circ} \mathrm{C} / \mathrm{min}$ until a final temperature of $300^{\circ} \mathrm{C}$ was reached. It was held at that temperature for $5 \mathrm{~min}$. The column was TDX-1, with a stationary phase thickness of $0.25 \mu \mathrm{m}$, a diameter of $0.25 \mathrm{~mm}$, and a length of $30 \mathrm{~m}$. The carrier gas was helium; the pressure was maintained at $69.4 \mathrm{kPa}$. The total flow rate was $13.9 \mathrm{~mL} / \mathrm{min}$ and the column flow rate was $1.22 \mathrm{~mL} / \mathrm{min}$., linear velocity was $40 \mathrm{~cm} / \mathrm{sec}$ and the split ratio was 10 . The ion source temperature was $250^{\circ} \mathrm{C}$ and the solvent cut time 4 min. Data collection was obtained on a full scan mode (40$600 \mu)$.

\section{REsults AND Discussion}

The term wax esters indicates long chain carboxylic acids with long chain alcohols. They are present in many marine species (SARGENT, 1978). Such long chain esters have frequently been found in organisms that experience short periods of food supply followed by long periods of food shortage. They play an important role in cuticular water proofing, buoyancy and energy metabolism (BEITTENMILLER, 1996). The presence of wax esters has also been reported from marine particulate matter. A mixture of saturated and unsaturated wax esters has been detected over a range of $\mathrm{C}_{28}-\mathrm{C}_{42}$ (WAKEMAN; FREW, 1982).

Individual saturated wax esters have been identified in different marine organisms. For example, hexadecanyl hexadecanoate $\left(\mathrm{C}_{32}\right)$ has been identified in the coral Sinularia micrclavate from China (ZHUJIN et al., 1990) while hexadecanyl octadecanoate $\left(\mathrm{C}_{34}\right)$ has been reported in the soft coral Sarcophyton $s p$ from China (ROSENBERG et al., 1982). Bandar et al., (1987) detected saturated $C_{36}$ wax esters in a marine organism from Sri Lanka. Various mass spectrometric methods have been established to identify waxy esters (AASEN et al., 1971). In these studies, it was concluded that each peak is composed of a number of wax esters that have the same total number of carbons but that differ in alkyl and acyl moieties. The purpose of our study was to characterize the wax esters in this new species of sponge. Mass spectrometry indicated the presence of four long-chain fatty acid esters (Figs 1-4) in the chloroform fraction (purified by preparative layer chromatography). These were identified as tetradecanyl tetradecanoate $\left(\mathrm{C}_{28} \mathrm{H}_{56} \mathrm{O}_{2}\right)$, tetradecanyl hexadecanoate $\left(\mathrm{C}_{30} \mathrm{H}_{62}\right)$, tetradecanyl 9-octadecenoate $\left(\mathrm{C}_{32} \mathrm{H}_{60} \mathrm{O}_{2}\right)$ and 9heptadecenyl nonadecanoate, $\mathrm{C}_{36} \mathrm{H}_{70} \mathrm{O}_{2}$. Thin Layer chromatography on silica plates was observed with solvent system (hexane:ether:acetic acid, 20:80:1, $\mathrm{v} / \mathrm{v})$; the plate was exposed to iodine vapors. The appearance of the spots indicated these compounds to be the major components (approximately $40 \%$ of the total spots), however no attempt was made to quantify them. 

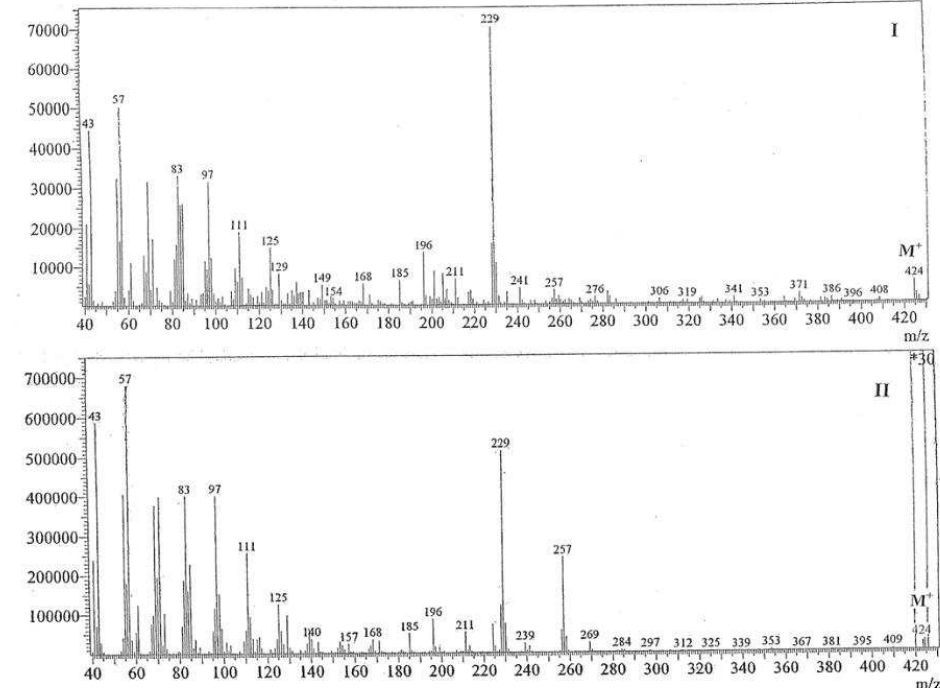

Fig. 1. Mass-spectrum of teradecanyl tetradecanoate (I) $\mathrm{C}_{28} \mathrm{H}_{56} \mathrm{O}_{2}(\mathrm{M} / \mathrm{Z}=4242)$ isolated from a sponge along coast of Jeddah. The CG-MS indicates the presence of one compound 14/14. The second GC-MS (II) indicates a mixtures of isomers containing chains of 14/14 and 12/16 carbon atoms.

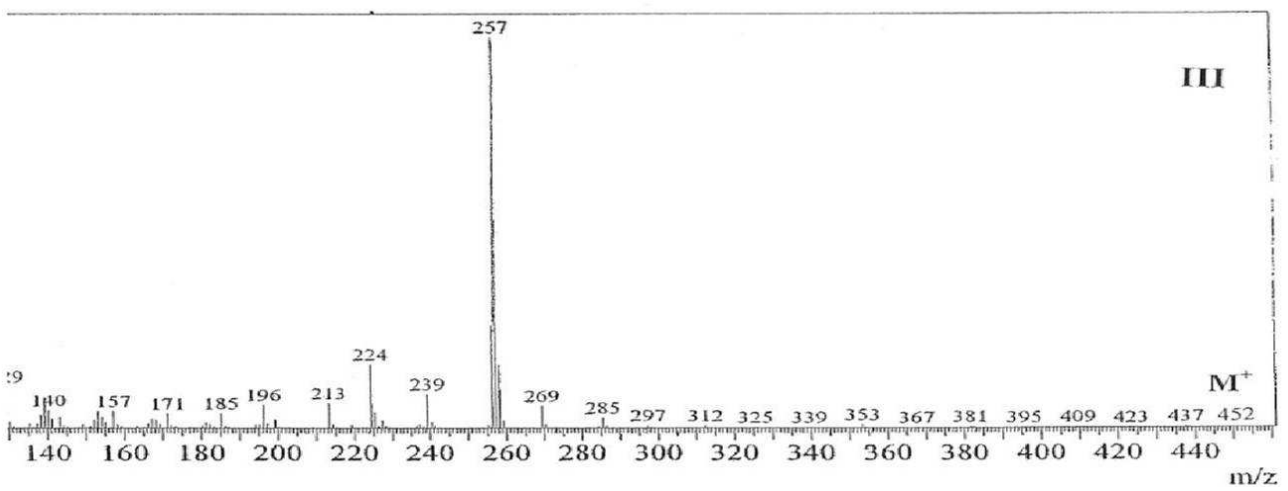

Fig. 2. Mass spectrum of tetrade canyl hexadecanoate (III) $\mathrm{C} 30 \mathrm{H} 60 \mathrm{O} 2(\mathrm{~m} / \mathrm{z}=452)$ from a sponge indicates the presence of one compound with 14/16 carbon chain.

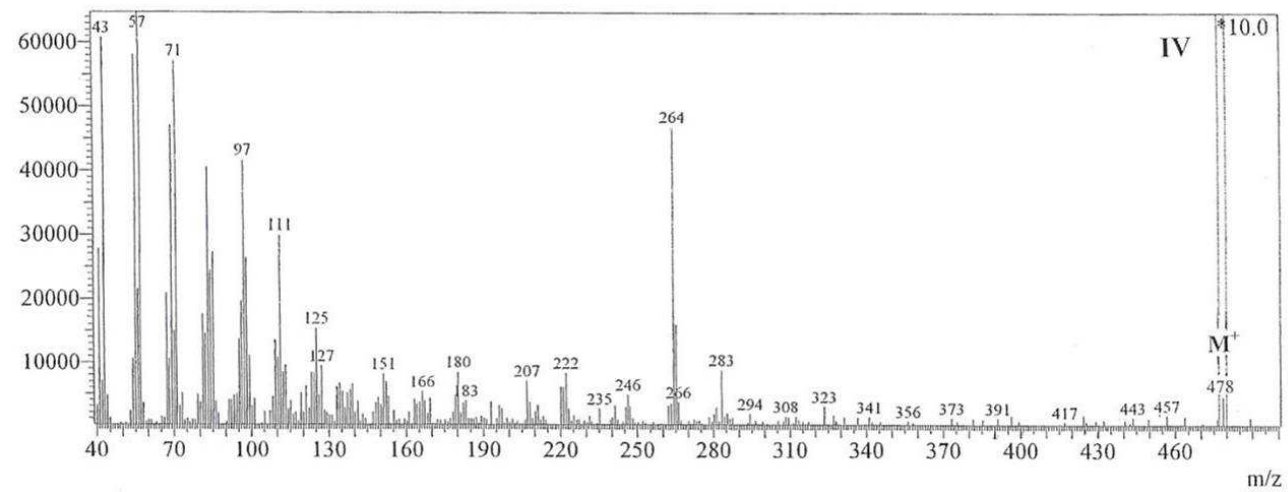

Fig. 3. Mass spectrum of tetradecanyl 9-octadecenoate (IV) $\mathrm{C}_{32} \mathrm{H}_{64} \mathrm{O}_{2}(\mathrm{~m} / \mathrm{z}=478)$ from a sponge indicates the presence of $16 / 18$ chain. 


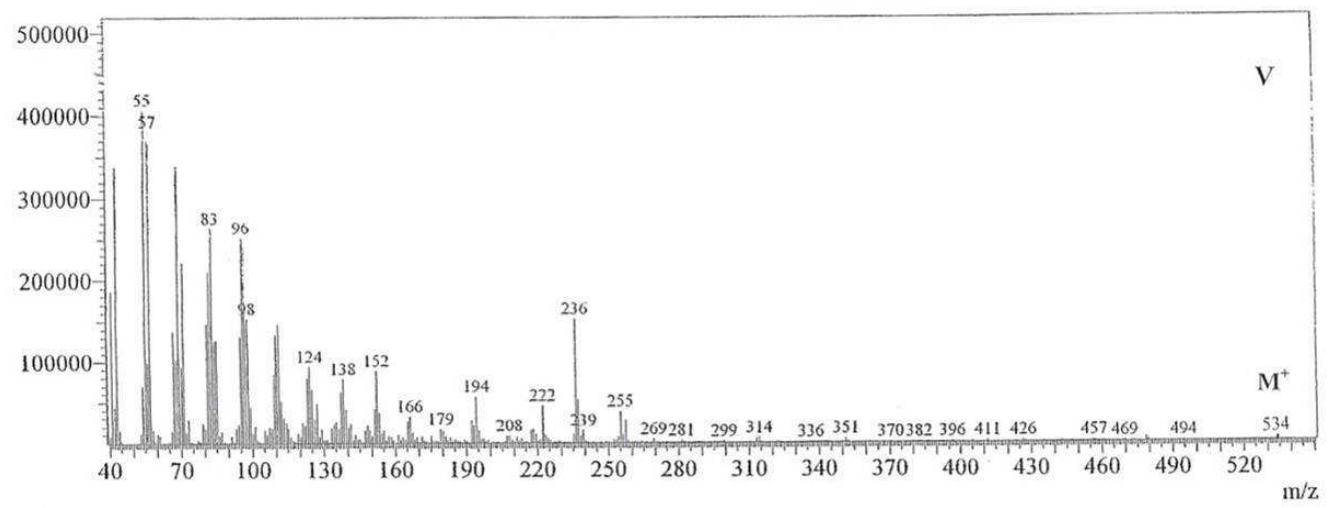

Fig. 4. Mass spectrum of 9-heptadecenyl nonadecanoate $(\mathrm{V}) \mathrm{C}_{32} \mathrm{H}_{70} \mathrm{O}_{2}(\mathrm{~m} / \mathrm{z}=534)$ from a sponge indicates the presence of $17 / 19$ chain.

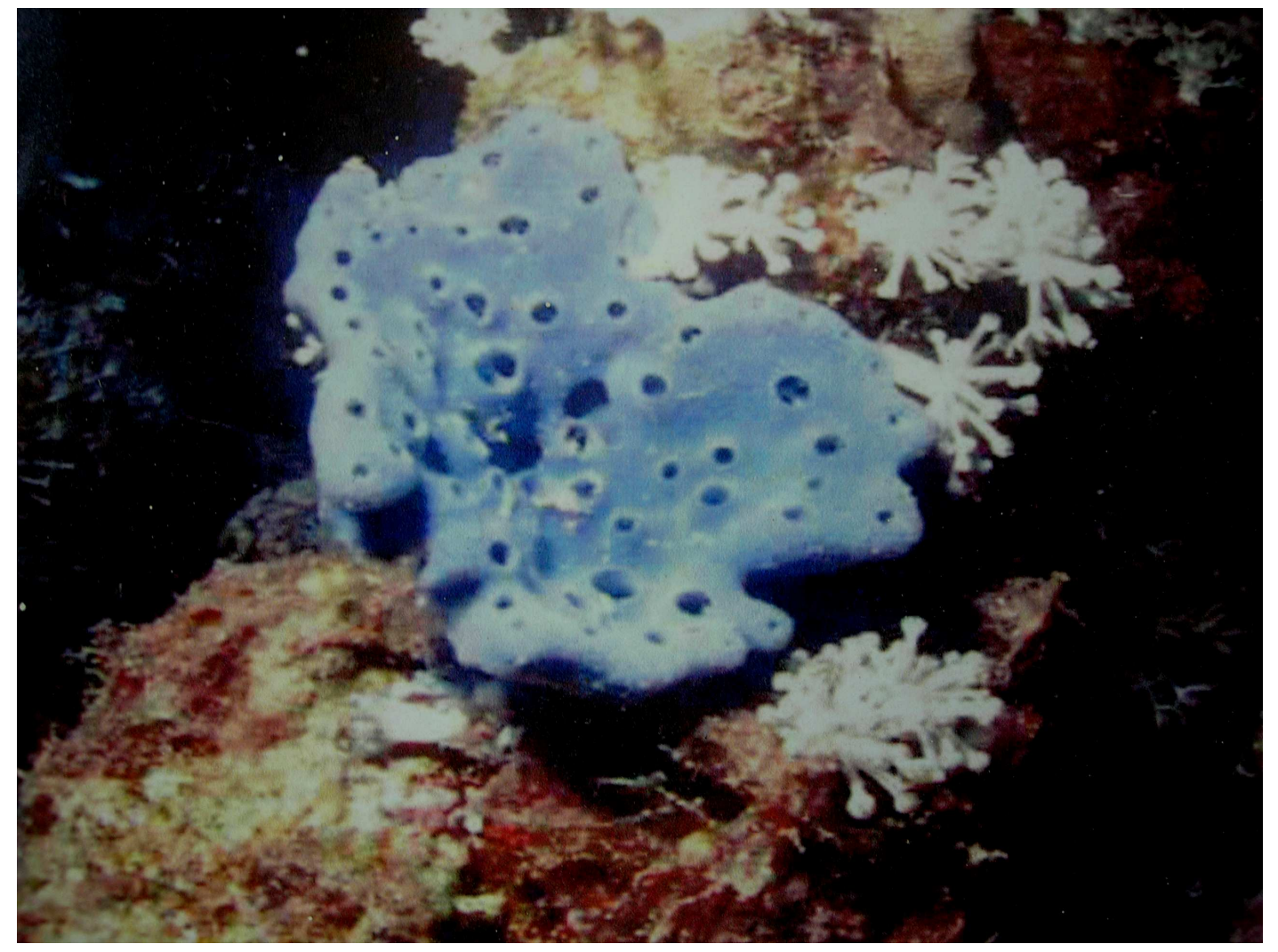

Fig. 5. Chalinula saudensis from the coast of Jeddah. The blue color is distinctly visible in the rocky bottom.

In the present study the GC quadruple was carefully examined to calculate the diagnostic ions, $\mathrm{R}^{\prime}$ being the alkyl group in the alcohol moiety and $\mathrm{R}$ being the acyl group in the acid moiety. The relative intensities of $\left[\mathrm{R}^{\prime-1}\right], \quad \mathrm{CO}_{2} \mathrm{R}^{\prime}, \quad \mathrm{CH}_{2}=\mathrm{C}(\mathrm{OH})-\mathrm{OR}$, $\mathrm{CH}_{2}=\mathrm{C}^{+}(\mathrm{OH}) \mathrm{R}^{\prime}$ were determined (Table 1). Similarly, the intensities of $\mathrm{R}$, the acyl group in the acid moiety were determined; it was calculated for $\left[\mathrm{RCO}_{2} \mathrm{H}-\right.$ 
Propyl $]^{+},\left[\mathrm{RCO}^{+} ;\left[\mathrm{RCO}_{2} \mathrm{H}\right]^{+}\right.$and $\left[\mathrm{RCOOH}_{2}\right]^{+}($Table 2). The ion $\left[\mathrm{RCO}_{2} \mathrm{H}\right]^{+}$could be formed by a MacLafferty rearrangement. It is also possible that the alkoxy fission with transfer of one hydrogen atom from position 2 is responsible for the formation of this ion; $\mathrm{RCO}_{2} \mathrm{H}^{+}$. $\mathrm{RCO}^{+}$and $\mathrm{RCO}_{2}{ }^{+}$ions are formed by the normal cleavage of the bonds adjacent to the carbonyl group. From these two tables it can be calculated that two isomers were possible for tetradecanyl tetradecanoate $\left(\mathrm{C}_{28} \mathrm{H}_{56} \mathrm{O}_{2}\right)$; these were in the ratios of 14:0/14:0 and 12:0/16:0, as is evident from the $\mathrm{m} / \mathrm{z} 229$ and 257 respectively, while the second compound $\left(\mathrm{C}_{28} \mathrm{H}_{56} \mathrm{O}_{2}\right)$ existed in 14:0/16:0 form. The third compound $\left(\mathrm{C}_{30} \mathrm{H}_{60} \mathrm{O}_{2}\right)$ showed the existence of one double bond at position 9 of the alcohol moiety, 14:1/16:0, giving one of the fragments $\left[\mathrm{R}^{\prime}-\mathrm{H}\right]$ at 236 . The molecular ion $\mathrm{m} / \mathrm{z} 534$ was not revealed in the GC-MS; however, comparison with the NIST library indicated $96 \%$ resemblance. Tetradecanyl 9-octadecanoate has previously been identified in the fire corals Millepora dichotoma and Millepora platyphylla (Al-LIHAIBI et al., 2002). It would be interesting to compare and contrast the results of other groups of workers (WAKEMAN; FREW, 1982) who isolated slightly different long chain fatty acid esters from particulate matter and stated that each of them existed in isomeric form. Reyhage and Stenhagen (1963) compared $\mathrm{C}_{32} \mathrm{H}_{62} \mathrm{O}_{2}$ with the one that was obtained synthetically. Compounds (II), (III) and (IV) were also isolated by Wakeman and Frew (1982) from biological and geochemical samples; our GC-MS seems to be identical with the one described by them.

Table 1. Intensities of characteristic ions containing the alcohol moiety in mass spectra of saturated and unsaturated wax esters of Chalinula saudensis from Red Sea coast.

\begin{tabular}{|c|c|c|c|c|c|c|c|c|c|c|c|c|c|c|c|c|}
\hline \multirow[t]{2}{*}{ No } & \multirow{2}{*}{$\begin{array}{l}\text { Molecular } \\
\text { Formula }\end{array}$} & \multicolumn{2}{|c|}{$\overline{\mathrm{M}}^{+}$} & \multirow[t]{2}{*}{ SI } & \multirow[t]{2}{*}{ R.T } & \multirow[t]{2}{*}{ Fraction } & \multirow{2}{*}{$\begin{array}{l}\text { Wax } \\
\text { Alcohol }\end{array}$} & \multirow{2}{*}{$\begin{array}{l}\text { Ester } \\
\text { Acid }\end{array}$} & \multicolumn{2}{|c|}{ 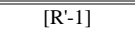 } & \multicolumn{2}{|c|}{$\mathrm{CO}_{2} \mathrm{R}^{+}$} & \multirow{2}{*}{$\begin{array}{l}\mathrm{CH}_{2}=\mathrm{C}^{+} \\
\text {Mass }\end{array}$} & \multirow{2}{*}{$\begin{array}{l}\mathrm{OH}^{+} \mathrm{OR}^{\prime} \\
\text { Int. }\end{array}$} & \multirow{2}{*}{$\begin{array}{l}\mathrm{CH}_{2}=\mathrm{C}^{+} \\
\text {Mass }\end{array}$} & \multirow{2}{*}{$\begin{array}{l}\mathrm{OH}_{2}{ }^{+} \mathrm{OR}^{\prime} \\
\text { Int. }\end{array}$} \\
\hline & & Mass & Int. & & & & & & Mass & Int. & Mass & Int. & & & & \\
\hline I & $\mathrm{C}_{28} \mathrm{H}_{56} \mathrm{O}_{2}$ & 424 & 7.76 & 89 & 26.22 & CS04 & 14 & 14 & 196 & 19.31 & 241 & 6.23 & 256 & 2.29 & 257 & 5.45 \\
\hline II & $\mathrm{C}_{28} \mathrm{H}_{56} \mathrm{O}_{2}$ & 424 & 0.12 & 91 & 27.74 & CS04 & 14 & 14 & 196 & 12.64 & 241 & 2.36 & 256 & 8.28 & 257 & 35.42 \\
\hline & & & & & & & 12 & 16 & 168 & 5.13 & 211 & 7.73 & 228 & 17.67 & 229 & 75.38 \\
\hline III & $\begin{array}{c}\mathrm{C}_{30} \mathrm{H}_{60} \mathrm{O}_{2} \\
\mathrm{a}\end{array}$ & 452 & 0.07 & 90 & 29.77 & CS04 & 14 & 16 & 196 & 6.31 & 241 & 0.66 & 256 & 26.50 & 257 & 100 \\
\hline IV & $\mathrm{C}_{32} \mathrm{H}_{62} \mathrm{O}_{2}$ & 478 & 0.62 & 91 & 29.48 & CS04 & 14 & $18^{\mathrm{c}}$ & 196 & 3.29 & 241 & 3.27 & 256 & 0.80 & 257 & 0.93 \\
\hline V & $\mathrm{C}_{36} \mathrm{H}_{70} \mathrm{O}_{2}$ & 534 & $---b$ & 92 & 29.57 & CS05 & $17^{\mathrm{d}}$ & 19 & 236 & 44.78 & 281 & 1.15 & 298 & 0.12 & 299 & 0.81 \\
\hline
\end{tabular}

a-Studied previously as a mixture of $14 / 16$ and 12/18 (Al- LIHAIBI et al. 1999).

b-Molecular weight according to NIST library.

c-Double bond present in the acyl moiety.

d-Double bond present in the alcohol moiety.

Table 2. Intensities of characteristic ions containing the acyl moiety in mass spectra of saturated and unsaturated wax esters of Chalinula saudensis from Red Sea coast.

\begin{tabular}{|c|c|c|c|c|c|c|c|c|c|c|c|c|c|c|c|c|}
\hline \multirow[t]{2}{*}{ No. } & \multirow[t]{2}{*}{$\begin{array}{l}\text { Molecular } \\
\text { Formula }\end{array}$} & \multicolumn{2}{|c|}{$\mathrm{M}^{+}$} & \multirow[t]{2}{*}{ SI } & \multirow[t]{2}{*}{ R.T } & \multirow[t]{2}{*}{ Fraction } & \multirow{2}{*}{$\begin{array}{l}\text { Wax } \\
\text { Alcohol }\end{array}$} & \multirow{2}{*}{$\begin{array}{l}\text { Ester } \\
\text { Acid }\end{array}$} & \multicolumn{2}{|c|}{$\begin{array}{c}\mathrm{RCO}_{2} \mathrm{H}^{+}- \\
\text {Propyl }\end{array}$} & \multicolumn{2}{|c|}{$\mathrm{RCO}^{+}$} & \multicolumn{2}{|c|}{$\mathrm{RCO}_{2} \mathrm{H}^{+}$} & \multicolumn{2}{|c|}{$\mathrm{RCO}_{2} \mathrm{H}_{2}^{+}$} \\
\hline & & Mass & Int. & & & & & & Mass & Int. & Mass & Int. & Mass & Int. & Mass & Int. \\
\hline I & $\mathrm{C}_{28} \mathrm{H}_{56} \mathrm{O}_{2}$ & 424 & 7.76 & 89 & 26.22 & CSO4 & 14 & 14 & 185 & 9.18 & 211 & 9.62 & 228 & 22.35 & 229 & 100 \\
\hline II & $\mathrm{C}_{28} \mathrm{H}_{56} \mathrm{O}_{2}$ & 424 & 0.12 & 91 & 27.74 & CS04 & 14 & 14 & 185 & 7.30 & 211 & 7.73 & 228 & 17.67 & 229 & 75.38 \\
\hline & & & & & & & 12 & 16 & 213 & 2.55 & 239 & 3.61 & 256 & 8.28 & 257 & 35.42 \\
\hline III & $\mathrm{C}_{30} \mathrm{H}_{60} \mathrm{O}_{2} \mathrm{a}$ & 452 & 0.07 & 90 & 29.77 & CS04 & 14 & 16 & 213 & 6.61 & 239 & 8.97 & 256 & 26.50 & 257 & 100 \\
\hline IV & $\mathrm{C}_{32} \mathrm{H}_{62} \mathrm{O}_{2}$ & 478 & 0.62 & 91 & 29.48 & CSO4 & 14 & $18^{\mathrm{c}}$ & 239 & 0.80 & 264 & 50.32 & 282 & 0.57 & 283 & 9.38 \\
\hline V & $\mathrm{C}_{36} \mathrm{H}_{70} \mathrm{O}_{2}$ & 534 & ----b & 92 & 29.57 & CS05 & $17^{\mathrm{d}}$ & 19 & 255 & 9.31 & 281 & 1.15 & 298 & 0.12 & 299 & 0.81 \\
\hline
\end{tabular}

a-Studied previously as a mixture of 14/16 and 12/18(WAKEMAN and FREW ,1982)

b-Molecular weight according to NIST library.

c-Double bond present in the acyl moiety.

d-Double bond present in the alcohol moiety

\section{Conclusion}

Chalinula saudensis is a sponge from the Jeddah coast that has been isolated and characterized taxonomically only recently. Four long-chain aliphatic wax esters from the sponge, $\mathrm{C}_{28} \mathrm{H}_{56} \mathrm{O}_{2}, \mathrm{C}_{30} \mathrm{H}_{60} \mathrm{O}_{2}$, $\mathrm{C}_{32} \mathrm{H}_{62} \mathrm{O}_{2}$ and $\mathrm{C}_{36} \mathrm{H}_{72} \mathrm{O}_{2}$, were isolated and identified for the first time. Each ester was composed of a total of from 28 to 36 carbon atoms. Only one of the esters, $\mathrm{C}_{30} \mathrm{H}_{60} \mathrm{O}_{2}$, has been reported previously from a marine species (the fire coral) although similar esters have been reported from a wide variety of marine organisms and marine particulate matter. The compound $\mathrm{C}_{28} \mathrm{H}_{56} \mathrm{O}_{2}$ occurred in two isomeric forms but each of the remaining compounds occurred as a single isomer. In marine organisms, wax esters probably function as an energy reserve (REINHART; VLEET, 1985). Further work will be needed to determine the precise location of these esters within the sponge and to characterize the biochemical pathways by which these compounds are produced. 


\section{REFERENCES}

AASEN, A. J.; HOFSTATER, H. H.; IYENGAR, B. T. R.; HOLMAN, R. T. Identification and analysis of wax esters by mass spectrometry. Lipids, v. 6, p. 502507,1971 .

Al-LIHAIBI, S. S.; Al-SOFYANI, A. M.; NIAZ, G. R.; AHMAD, V. U.; NOORWALA, M.; MOHAMMED, F. $\mathrm{V}$. Long chain wax esters and diphenylamine in fire coral Millepora dichotoma and Millepora platyphylla from Saudi Red Sea coast. Scient. Mar.,v.66 ,n.2, p. 95- 102, 2000.

BANDRA, B. M. R.; GUNATILIKA, A. A. L.; SAMARANAYKE, S. D. G. S.; de SILVA, E. D.; TILKERATNE, L. M. V. Chemistry of marine organisms of Sri Lanka: lipid and triterpenoid constituents of an unidentified Alyconacean and an unidentified holothurin, J. nat. Sci. Coun., v. 15, p.101$108,1987$.

BEITTENMILLER, D. P. Biochemistry and molecular biology of wax production in plants, Ann. Review of Plant Physiol. Mol. Biol., v. 47, p.405- 430, 1996.

RYHAGE, R.; STENHAGEN, E. In: MACLAFFERTY, F.W. (Ed.). Mass Spectrometry of organic ions. New York: Academic Press, 1963. p. 399- 412.

SARGENT, J. R. Marine Wax esters. Sci. Prog., v. 65, p. 437- 458, 1978.
Vacelet, J.; Al-SOFYANI, A. M.; Al-LIHAIBI, S. S.; KORNPRPBST, J. M. A new Haplscelroid sponge from Saudi Red Sea Coast. J. mar. biol. Ass., UK, v. 81, p. 943-948, 2001.

REINHART, S. B.; VAN-VLEET, E. S. Lipid composition of twenty-two species of Antarctic midwater zooplankton fish. Mar. Biol., v. 91, n. 2 , p. 149- 159, 1985.

ROSENBERG, L.; ZAGI, L.; KANGHU, L. Studies on the chemical constituents of Chinese soft coral (Sarcophyton) Zhongshan Dauxue Xuebao, Ziran Kexueban, v.1, 1982. p.78-81.

WAKEMAN, S. G.; FREW, N. M. Glass capillary gas chromatography - mass spectrometry of wax esters, stearyl esters, and triglycerides. Lipids, v. 17, p.831 $843,1982$.

ZHUJIN, L.; JIANGSION, L.; HOMING,W. A study on the chemical constituents of South China Sea soft coral Sinularia microclavate . Younge Hauxue, v.10, p. $277-$ 281, 1990.

(Manuscript received 04 January 2009; revised 14 April 2010; accepted 04 November 2010) 